\title{
Remarkable Oxidation Stability of Glycals: Excellent Substrates for Cerium(IV)-Mediated Radical Reactions
}

\author{
Torsten Linker, ${ }^{*, \dagger}$ Dirk Schanzenbach, ${ }^{\dagger}$ Elangovan Elamparuthi, ${ }^{\dagger}$ \\ Thomas Sommermann, ${ }^{\dagger}$ Werner Fudickar, ${ }^{\dagger}$ Viktor Gyóllai, ${ }^{\ddagger}$ László Somsák, ${ }^{\ddagger}$ \\ Wolfgang Demuth, ${ }^{\S}$ and Michael Schmittel ${ }^{\S}$ \\ Department of Chemistry, University of Potsdam, Karl-Liebknecht-Strasse 24-25, \\ D-14476 Potsdam, Germany, Department of Organic Chemistry, University of Debrecen, \\ P.O. Box 20, H-4010 Debrecen, Hungary, and Department of Chemistry, University of Siegen, \\ Adolf Reichwein Strasse 2, D-57068 Siegen, Germany
}

Received July 8, 2008; E-mail: linker@chem.uni-potsdam.de

\section{Introduction}

Glycals (1,5- or 1,4-anhydrohex(pent)-1-enitols) $\mathbf{1}$ are 1,2unsaturated carbohydrate derivatives that were described and denominated by Emil Fischer almost 100 years ago. ${ }^{1}$ Their synthesis is easily accomplished by reductive elimination of $O$-protected glycosyl halides on a large scale, ${ }^{2}$ and several of the most prominent and widely used glycals (e.g., tri- $O$-acetylD-glucal, 1a) are nowadays commercially available.
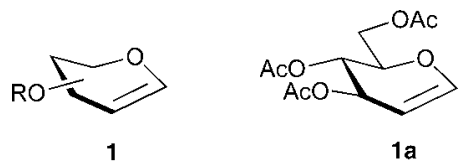

Glycals have been applied as enantiomerically pure starting materials for various stereoselective transformations ${ }^{3}$ and the

${ }^{\dagger}$ University of Potsdam.

* University of Debrecen.

$\S$ University of Siegen.

(1) (a) Fischer, E.; Zach, K. Chem. Zentralbl. 1913, 1668-1669. (b) Fischer, E. Chem. Ber. 1914, 47, 196-210.

(2) (a) Ferrier, R. J. Adv. Carbohydr. Chem. 1965, 20, 67-137. (b) Ferrier, R. J. Adv. Carbohydr. Chem. 1969, 24, 199-266. (c) Somsák, L. Chem. Rev. 2001, 101, 81-135. (d) Ferrier, R. J.; Hoberg, J. O. Adv. Carbohydr. Chem. Biochem. 2003, 58, 55-119.

(3) (a) Tolstikov, A. G.; Tolstikov, G. A. Russ. Chem. Rev. 1993, 62, 579-601. (b) PriebeW.; Grynkiewicz, G. In Glycoscience: Chemistry \& Chemical Biology; Fraser-Reid, B. O., Tatsuta, K., Thiem, J., Eds.; Springer: Berlin, 2001; Vol. 1, pp 749-783. (c) Taillefumier, C.; Chapleur, Y. Chem. Rev. 2004, 104, 263-292. total synthesis of natural products ${ }^{4}$ and as enzyme inhibitors. ${ }^{5}$ Importantly, epoxidation of glycals, discovered in the seminal work of Danishefsky, resulted in many examples from the synthesis of biologically interesting oligosaccharides and glycoconjugates. ${ }^{6}$ While dimethyldioxirane (DMDO) is a convenient reagent for this transformation, other oxidants such as methyltrioxorhenium (MTO) have received growing attention recently. ${ }^{7}$ These reactions work remarkably well with glycals 1, whereas simple cyclic enol ethers such as 2,3-dihydropyran are easily cleaved under acidic conditions or in the presence of

(4) (a) Hanessian, S. Total Synthesis of Natural Products: The "Chiron" Approach; Pergamon: Oxford, 1983. (b) Fraser-Reid, B. O. In Strategies and Tactics in Organic Synthesis; Lindberg, T., Ed.; Academic Press: New York, 1989; Vol. 2, pp 123-149. (c) Very recent example: Denmark, S. E.; Regens, C. S.; Kobayashi, T. J. Am. Chem. Soc. 2007, 129, 2774-2776.

(5) (a) Chenault, H. K.; Mandes, R. F. Bioorg. Med. Chem. 1994, 2, 627 629. (b) Lai, E. C.; Morris, S. A.; Street, I. P.; Withers, S. G. Bioorg. Med. Chem. 1996, 4, 1929-1937. (c) Stolz, F.; Reiner, M.; Blume, A.; Reutter, W.; Schmidt, R. R. J. Org. Chem. 2004, 69, 665-679.

(6) (a) Danishefsky, S. J.; Bilodeau, M. T. Angew. Chem., Int. Ed. Engl. 1996, 35, 1380-1419. (b) Seeberger, P. H.; Danishefsky, S. J. Acc. Chem. Res. 1998, 31, 685-695. (c) Seeberger, P. H.; Haase, W.-C. Chem. Soc. Rev. 2000, 100, 4349-4393. (d) Danishefsky, S. J.; Allen, J. R. Angew. Chem., Int. Ed. 2000, 39, 836-863. (e) Nicolaou, K. C.; Mitchell, H. J. Angew. Chem., Int. Ed. 2001, 40, 1576-1624. (f) Cheshev, P.; Marra, A.; Dondoni, A. Carbohydr. Res. 2006, 341, 27142716.

(7) (a) Soldaini, G.; Cardona, F.; Goti, A. Tetrahedron Lett. 2003, 44, 5589-5592. (b) Goti, A.; Cardona, F.; Soldaini, G.; Crestini, C.; Fiani, C.; Saladino, R. Adv. Synth. Catal. 2006, 348, 476-486. 
Chart 1. Glycals $1 \mathbf{a}-\mathbf{w}$ with Various Configurations and Protecting Groups
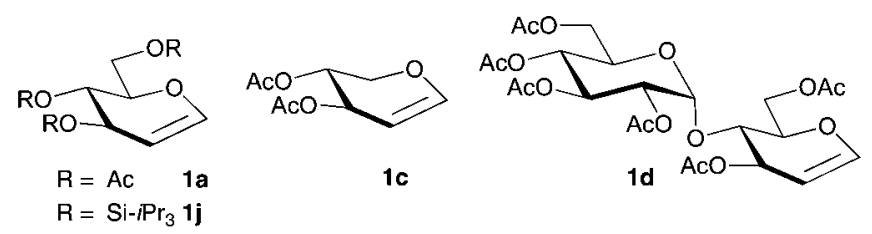
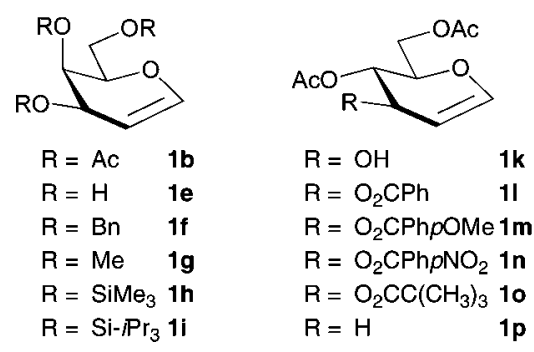

manganese(III). ${ }^{8}$ Interestingly, the oxidation of glycals with hypervalent iodine reagents affects only the allylic position and leaves the double bond intact. ${ }^{9}$

During the course of our investigations on transition-metalmediated radical reactions, ${ }^{10}$ we became interested in the addition of malonates to various glycals $\mathbf{1}$ in the presence of cerium(IV) ammonium nitrate (CAN). ${ }^{11}$ This reaction is similar to Lemieux's azidonitration, ${ }^{12}$ but provides easy access to $C$-2branched carbohydrates, a valuable complement to the cyclopropanation of glycals. ${ }^{13}$ More recently, we applied this methodology to other $\mathrm{CH}$ acidic radical precursors (e.g., nitromethane or nitro esters) ${ }^{14}$ and to unsaturated carbohydrates with benzyl protecting groups. ${ }^{15}$ In all cases, the double bond of glycals 1 was not directly affected by CAN, although this reagent has an oxidation power $\left(E_{1 / 2}{ }^{\text {ox }}=1.52-1.60 \mathrm{~V}\right.$ vs NHE $)^{16}$ sufficient to oxidize unsubstituted 2,3-dihydropyran $\left(E_{\mathrm{pa}}\right.$ $=1.60 \mathrm{~V}$ vs NHE) ${ }^{17}$ Furthermore, the addition of radicals to 2,3-dihydropyran was not successful. ${ }^{8 \mathrm{~d}}$ Thus, glycals $\mathbf{1}$ exhibit

(8) (a) Fife, T. H. J. Am. Chem. Soc. 1965, 87, 1084-1089. (b) Piancatelli, G.; Scettri, A.; D'Auria, M. Tetrahedron Lett. 1977, 18, 3483-3484. (c) Baskaran, S.; Islam, I.; Raghavan, M.; Chandrasekaran, S. Chem. Lett. 1987, 1175-1178. (d) Narasaka, K.; Mochizuki, T.; Hayakawa, S. Chem. Lett. 1994, 1705-1708.

(9) (a) Kirschning, A.; Dräger, G.; Harders, J. Synlett 1993, 289-290. (b) Kirschning, A. Eur. J. Org. Chem. 1998, 2267-2274. (c) Kirschning, A.; Hary, U.; Plumeier, C.; Ries, M.; Rose, L. J. Chem. Soc., Perkin Trans. 1 1999, 519-528.

(10) (a) Linker, U.; Kersten, B.; Linker, T. Tetrahedron 1995, 51, $9917-$ 9926. (b) Linker, T.; Linker, U. Angew. Chem., Int. Ed. 2000, 39, 902-904. (c) Linker, T. J. Organomet. Chem. 2002, 661, 159-167.

(11) (a) Linker, T.; Hartmann, K.; Sommermann, T.; Scheutzow, D.; Ruckdeschel, E. Angew. Chem., Int. Ed. Engl. 1996, 35, 1730-1732. (b) Linker, T.; Sommermann, T.; Kahlenberg, F. J. Am. Chem. Soc. 1997, 119, 9377-9384. (c) Gyóllai, V.; Schanzenbach, D.; Somsák, L.; Linker, T. Chem. Commun. 2002, 1294-1295.

(12) Lemieux, R. U.; Ratcliffe, R. M. Can. J. Chem. 1979, 57, 1244-1251.

(13) Review: Cousins, G. S.; Hoberg, J. O. Chem. Soc. Rev. 2000, 29, $165-174$.

(14) (a) Sommermann, T.; Kim, B. K.; Peters, K.; Peters, E.-M.; Linker, T. Chem. Commun. 2004, 2624-2625. (b) Elamparuthi, E.; Linker, T. Org. Lett. 2008, 10, 1361-1364.

(15) (a) Yin, J.; Spindler, J.; Linker, T. Chem. Commun. 2007, 2712-2713. (b) Yin, J.; Sommermann, T.; Linker, T. Chem.-Eur. J. 2007, 13, 10152-10167.

(16) (a) CRC Handbook of Chemistry and Physics; Weast, R. C., Ed.; CRC Press: Boca Raton, FL, 1986. (b) Fokin, A. A.; Peleshanko, S. A.; Gunchenko, P. A.; Gusev, D. V.; Schreiner, P. R. Eur. J. Org. Chem. 2000, 3357-3362.

(17) (a) Linker, T.; Schmittel, M. Radikale und Radikalionen in der Organischen Synthese; Wiley-VCH: Weinheim, Germany, 1998. (b) Huo, C.; Jia, X.; Zhang, W.; Yang, Li.; Lü, J.; Liu, Z.-L. Synlett 2004, 251-254.

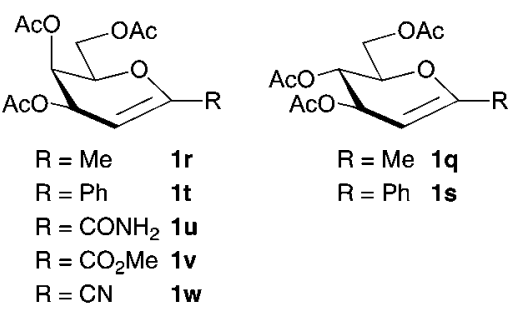

a reactivity remarkably different from that of simple cyclic enol ethers, which has been disregarded previously.

Herein, we describe a comprehensive study on the oxidation stability of variously substituted glycals $\mathbf{1}$ by a combination of cyclic voltammetry (CV), calculation of HOMO energies, and product distribution studies from radical additions. The present results establish a strong influence of protecting groups and of substitution patterns both in the allylic 3-position and in position 1 of the double bond on the oxidation potentials. Furthermore, our studies provide a rationale for the unusual reactivity of glycals compared to simple enol ethers, demonstrating their value as stable starting materials for radical and other oxidative transformations.

\section{Results}

Synthesis of Glycals 1. To investigate the oxidation stability of a broad variety of glycals, we synthesized more than 20 different 1,2-unsaturated carbohydrate derivatives. The simple $O$-acetyl-protected glycals $\mathbf{1 a}-\mathbf{d}$ were easily available from the parent glycosyl bromides for pentoses, hexoses, and disaccharides on a large scale via known procedures., ${ }^{2,18}$ For further functionalized systems, we focused on derivatives of D-glucal and D-galactal, which furnished high yields and selectivities in radical additions in our previous studies. ${ }^{11}$ Thus, the protecting groups were easily exchanged by literature procedures, ${ }^{19}$ and glycals $\mathbf{1 e}-\mathbf{j}$ were obtained in one- or two-step reactions from the corresponding tri- $O$-acetyl-D-glycals $\mathbf{1 a}$ and $\mathbf{1 b}$ (Chart 1 , Supporting Information). To investigate the influence of various substituents adjacent to the double bond, we altered the structures in the 1- and 3-positions of the glycals requiring some more laborious transformations. The 3 - $O$-acetyl group of glucal 1a was selectively removed by enzymatic saponification to give $\mathbf{1 k},{ }^{20}$ and subsequent reaction with acid chlorides afforded esters

(18) (a) Helferich, B.; Mulcahy, E. N.; Ziegler, H. Chem. Ber. 1954, 87, 233-237. (b) Somsák, L.; Németh, I. J. Carbohydr. Chem. 1993, 12, 679-684. (c) Shull, B. K.; Wu, Z.; Koreeda, M. J. Carbohydr. Chem. 1996, 15, 955-964. (d) Mitchell, S. A.; Pratt, M. R.; Hruby, V. R.; Polt, R. J. Org. Chem. 2001, 66, 2327-2342.

(19) (a) Overend, W. G.; Shafizadeh, F.; Stacey, M. J. Chem. Soc. 1950, 671-677. (b) Chmielewski, M.; Kaluza, Z. Carbohydr. Res. 1987, 167, 143-152. (c) Szeja, W.; Fokt, I.; Grynkiewicz, G. Recl. Trav. Chim. Pays-Bas 1989, 108, 224-226. (d) Chmielewski, M.; Fokt, I.; Grodner, J.; Grynkiewicz, G.; Szeja, W. J. Carbohydr. Chem. 1989, 8, 735744. (e) Madhusudan, S. K.; Agnihotri, G.; Negi, D. S.; Misra, A. K. Carbohydr. Res. 2005, 340, 1373-1377. (f) Ghosh, R.; Chakraborty, A.; Maiti, D. K.; Puranik, V. G. Org. Lett. 2006, 8, 1061-1064.

(20) Holla, W. E. J. Carbohydr. Chem. 1990, 9, 113-119. 
Table 1. Oxidation Potentials $\left(E_{\mathrm{ox}}\right)$ of Various Glycals 1 Determined by CV and Addition of Dimethyl Malonate (2)

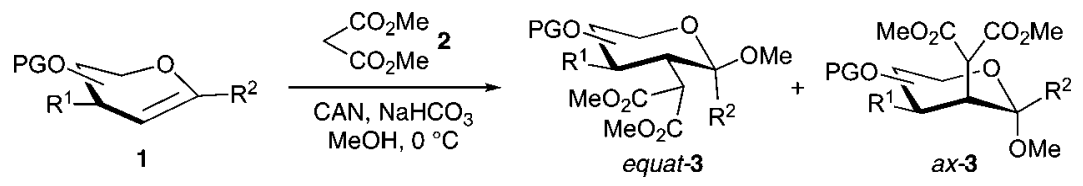

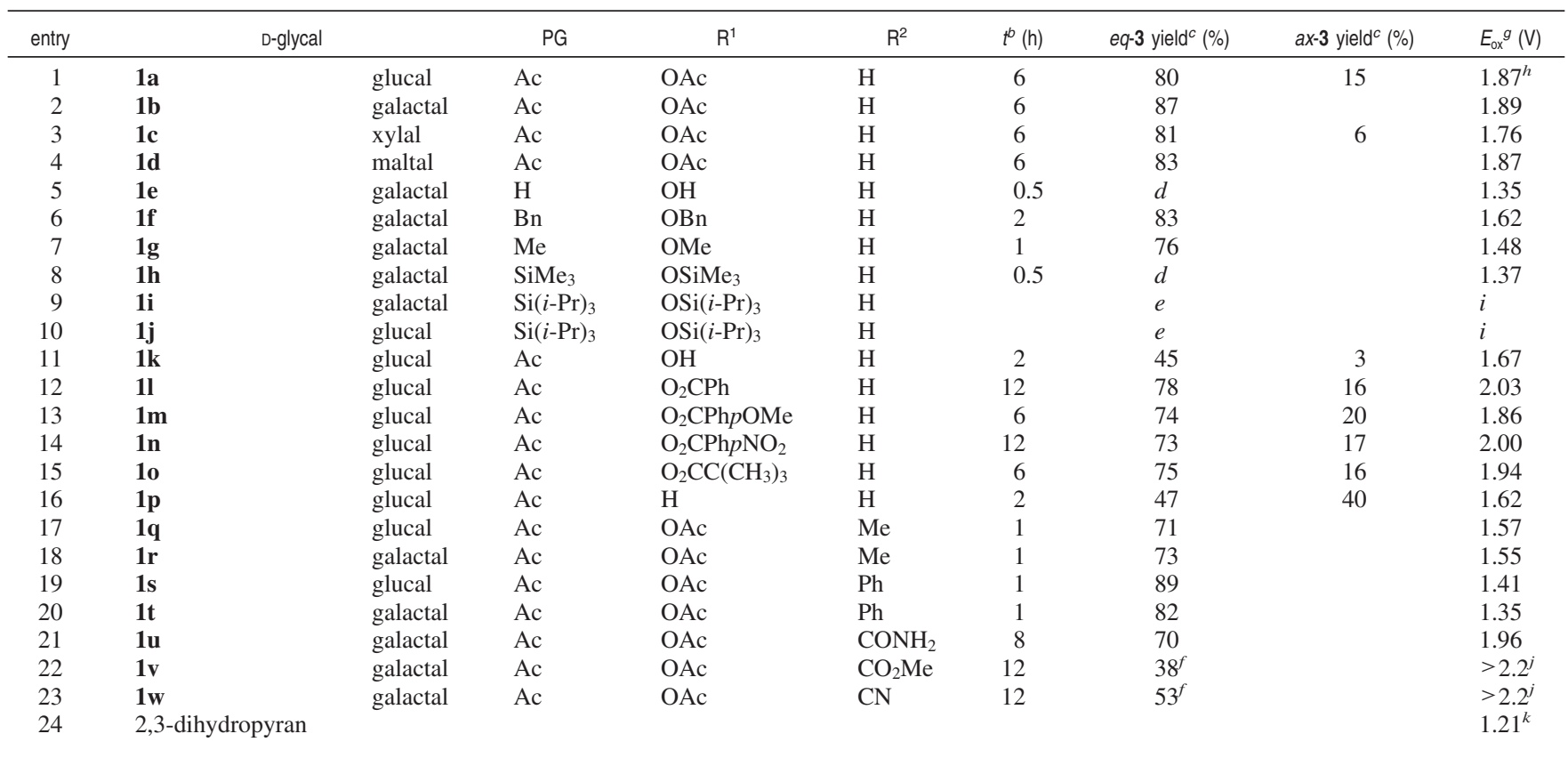

${ }^{a}$ Reaction of glycal $1(1.0 \mathrm{mmol})$ with malonate $2(10 \mathrm{mmol})$ in the presence of anhydrous CAN $(3-6 \mathrm{mmol})$ and $\mathrm{NaHCO} 3(4.0 \mathrm{mmol})$ in $\mathrm{MeOH}$ $(10 \mathrm{~mL})$ at $0{ }^{\circ} \mathrm{C} .{ }^{b}$ Reaction time until TLC showed complete conversion of glycal $1 .{ }^{c}$ Yield of isolated product after column chromatography. ${ }^{d}$ Decomposition of glycal $\mathbf{1} .{ }^{e}$ Glycals $\mathbf{1 i}$ and $\mathbf{1 j}$ were not soluble in methanol. ${ }^{f}$ Formation of ortho esters $\mathbf{4}$ and other minor side products. ${ }^{g}$ Oxidation potentials $E_{\mathrm{ox}}(\mathrm{V})$ obtained from cyclic voltammograms from the anodic peak potential. Determined at $100 \mathrm{mV} / \mathrm{s}$ in acetonitrile $\left(10^{-3} \mathrm{M}\right)$ in the presence of $\mathrm{Bu}_{4} \mathrm{NPF}_{6}(0.1 \mathrm{M})$ vs ferrocene. ${ }^{h}$ Literature value $1.80 \mathrm{~V} \cdot{ }^{27}{ }^{i}$ Glycals $\mathbf{1 i}$ and $\mathbf{1 j}$ were not soluble in acetonitrile. ${ }^{j}$ No oxidation peak was observed, due to dominating oxidation of the bare electrolyte solution at $E_{\mathrm{ox}}>2.2 \mathrm{~V}$. ${ }^{k}$ Literature value $1.20 \mathrm{~V} .{ }^{17}$

11-o in high yields (Supporting Information). Finally, 3-deoxyglucal 1p was obtained by Ferrier rearrangement and reduction with lithium aluminum hydride. ${ }^{21}$

To alter the electronic nature of the double bond, which should have an influence on the oxidation stability, we introduced donor and acceptor groups into the 1-position. Due to the acidity of the vinylic position, deprotonation of silylprotected glycals is possible with strong bases. ${ }^{2 \mathrm{c}, 22}$ After alkylation or arylation and exchange of the protecting groups, the 1-C-methyl- and 1-C-phenylglycals $\mathbf{1 q}-\mathbf{t}$ were isolated in moderate to good overall yields in analytically pure form (Chart 1 , Supporting Information). Acceptor-substituted galactals $1 \mathbf{u}^{23 a}$ and $1 \mathbf{w}^{23 \mathrm{~b}}$ were prepared by methods published earlier. Ester $\mathbf{1 v}^{23 \mathrm{c}}$ was obtained from $C$-(3,4,6-tri- $O$-acetyl-2-deoxy-D-lyxohex-1-enopyranosyl)carbaldehyde by oxidation with $\mathrm{MnO}_{2}$ and subsequent in situ esterification (Chart 1, Supporting Information). In summary, we have synthesized more than 20 different glycals $\mathbf{1}$, some of which were hitherto unknown. Due to the broad variation of the substitution pattern, these unsaturated

(21) Fraser-Reid, B. O.; Tam, Y.-K.; Radatus, B. Can. J. Chem. 1975, 53, 2005-2016.

(22) (a) Friesen, R. W.; Sturino, C. F.; Daljeet, A. K.; Kolaczewska, A. J. Org. Chem. 1991, 56, 1944-1947. (b) Majumder, U.; Cox, J. M.; Rainier, J. D. Org. Lett. 2003, 5, 913-916. (c) Lehmann, U.; Awasthi, S; Minehan, T. Org. Lett. 2003, 5, 2405-2408.

(23) (a) Somsák, L. Carbohydr. Res. 1989, 195, C1-C2. (b) Somsák, L.; Bajza, I.; Batta, G. Liebigs Ann. Chem. 1990, 1265-1268. (c) Mahmoud, S. H.; Somsák, L.; Farkas, I. Carbohydr. Res. 1994, 254, 91-104. (d) Banaszek, A. Tetrahedron 1995, 51, 4231-4238. (e) Kiss, L.; Somsák, L. Carbohydr. Res. 1996, 291, 43-52. carbohydrates should provide sufficient information for the subsequent studies.

Cyclic Voltammetry of Glycals 1. Although anodic and PET oxidations of enol ethers are of significant synthetic interest, their oxidation potentials are not well established. ${ }^{17,24}$ Besides oxidative DNA damage via nucleotide radical cations, whose kinetics has been thoroughly studied, ${ }^{25}$ the oxidation potential of only one glycal, i.e., tri- $O$-acetyl-D-glucal (1a), has been described until now. ${ }^{26}$ Therefore, we investigated the redox behavior of various glycals 1 by CV (Table 1 ). ${ }^{27}$ All measurements were conducted in dry acetonitrile with tetra- $n$-butylammonium hexafluorophosphate $\left(\mathrm{Bu}_{4} \mathrm{NPF}_{6}\right)$ as the supporting electrolyte applying a scan rate of $100 \mathrm{mV} / \mathrm{s}$ (Supporting Information). Most glycals were readily soluble, except the silyl-

(24) (a) Koch, D.; Schäfer, H.; Steckhan, E. Chem. Ber. 1974, 107, 36403657. (b) Lopez, L.; Troisi, L. Tetrahedron Lett. 1989, 30, 489-492. (c) Moeller, K. D.; Marzabadi, M. R.; New, D. G.; Chiang, M. Y.; Keith, S. J. Am. Chem. Soc. 1990, 112, 6123-6124. (d) Schmittel, M.; Röck, M. Chem. Ber. 1992, 125, 1611-1620. (e) Schmittel, M.; Burghart, A. Angew. Chem., Int. Ed. Engl. 1997, 36, 2550-2589. (f) Bernhard, K.; Geimer, J.; Canle-Lopez, M.; Reynisson, J.; Beckert, D.; Gleiter, R.; Steenken, S. Chem.-Eur. J. 2001, 7, 4640-4650.

(25) (a) Newcomb, M.; Miranda, N.; Huang, X.; Crich, D. J. Am. Chem. Soc. 2000, 122, 6128-6129. (b) Newcomb, M.; Miranda, N.; Sannigrahi, M.; Huang, X.; Crich, D. J. Am. Chem. Soc. 2001, 123, 64456446 , and references therein.

(26) (a) Klemer, A.; Nicolaus, A. Chem. Ber. 1979, 112, 3063-3071. (b) Colovic, M.; Vukicevic, M.; Segan, D.; Manojlovic, D.; Sojic, N.; Somsák, L.; Vukicevic, R. D. Adv. Synth. Catal. 2008, 350, 29-34.

(27) Savéant, J.-M. Elements of Molecular and Biomolecular Electrochemistry, Wiley: Hoboken, NJ, 2006. 
protected derivatives $\mathbf{1 i}$ and $\mathbf{1 j}$. The cyclic voltammograms of glycals 1 displayed irreversible oxidation peaks in the broad range from 1.35 to $2.03 \mathrm{~V}$ vs ferrocene, which are remarkably higher than that of 2,3-dihydropyran (1.21 V, entry 24). Furthermore, the oxidation potential $\left(E_{\mathrm{ox}}\right)$ of the acceptorsubstituted carbohydrates $\mathbf{1 v}$ and $\mathbf{1 w}$ must be very high $\left(E_{\mathrm{OX}}>\right.$ $2.2 \mathrm{~V}$, entries 22 and 23), since only the anodic current of the bare electrolyte solution was observed. As is typical for chemical follow-up reactions after the electron transfer step, i.e., for EC or ECE mechanisms, the anodic peak of all glycals shifted to higher potentials with increasing scan rate, with the peak current dropping in the second sweep. ${ }^{28}$ In summary, for the first time we obtained a whole data set of oxidation potentials of a broad variety of glycals 1. The high values of $1.35-2.03 \mathrm{~V}$ vs ferrocene demonstrate their remarkable oxidation stability and the strong influence of the substitution pattern on their reactivity.

Radical Additions to Glycals 1. Radical reactions in the presence of tri- $n$-butyltin hydride have become an important methodology for the selective formation of carbon-carbon bonds. ${ }^{29}$ Electrophilic radicals, typically characterized by adjacent acceptor groups, are conveniently generated by transitionmetal-mediated oxidation of $\mathrm{CH}$ acidic precursors. ${ }^{30}$ In previously reported addition reactions of such radicals to glycals $\mathbf{1 a}-\mathbf{c}$, the enol ether structure was not directly affected by CAN and the $C$-2-branched analogues $\mathbf{3}$ were isolated in high yields. ${ }^{11}$ To examine the scope and limitations of the addition of dimethyl malonate (2) and to find an explanation for the remarkable oxidation stability of glycals $\mathbf{1}$, we compared more than 20 substrates (Table 1, Supporting Information). Reaction times, which are indicative of the reactivity of the glycals $\mathbf{1}$ toward the electrophilic malonyl radicals, were measured by monitoring full conversion by thin layer chromatography (TLC). The rate of addition was expected to reflect the electronic nature of the double bond and should correlate with the determined redox potentials (see the Discussion).

Additions to the per- $O$-acetylated glycals $\mathbf{1 a}-\mathbf{d}$ proceeded smoothly within $6 \mathrm{~h}$, affording products 3 in high overall yields (entries 1-4). The exclusive formation of one regioisomer and the higher selectivity observed with galactals have already been explained in our previous studies. ${ }^{11}$ No influence of the configuration on the reaction time was observed. On the other hand, the protecting groups altered the reactivity of the glycals $\mathbf{1 e}-\mathbf{h}$ remarkably (entries 5-8). The benzyl- and methylsubstituted substrates $\mathbf{1 f}$ and $\mathbf{1 g}$ gave already faster conversions and still high yields of the addition products $\mathbf{3 f}$ and $\mathbf{3 g}$ (entries 6 and 7), whereas the completely unprotected (1e) and tri-

(28) Nicholson, R. S.; Shain, I. Anal. Chem. 1964, 36, 706-723.

(29) (a) Giese, B. Radicals in Organic Synthesis: Formation of CarbonCarbon Bonds; Pergamon Press: Oxford, U.K., 1986. (b) HoubenWeyl, Methods of Organic Chemistry, 4th ed.; Regitz, M., Giese, B., Eds.; Thieme: Stuttgart, Germany, 1989; Vol. E19a. (c) Fossey, J.; Lefort, D.; Sorba, J. Free Radicals in Organic Chemistry; Wiley: Chichester, U.K., 1995. (d) Curran, D. P.; Porter, N. A.; Giese, B. Stereochemistry of Radical Reactions; VCH: Weinheim, Germany, 1996. (e) Radicals in Organic Synthesis; Renaud, P., Sibi, M. P., Eds.; Wiley-VCH: Weinheim, Germany, 2001. (f) Zard, S. Z. Radical Reactions in Organic Synthesis; Oxford University Press: New York, 2003. (g) Gansäuer, A. Radicals in Synthesis; Topics in Current Chemistry, Vol. 263; Springer: Berlin, 2006.

(30) (a) Iqbal, J.; Bhatia, B.; Nayyar, N. K. Chem. Rev. 1994, 94, 519564. (b) Dalko, P. I. Tetrahedron 1995, 51, 7579-7653. (c) Snider, B. B. Chem. Rev. 1996, 96, 339-363. (d) Melikyan, G. G. Org. React. 1996, 49, 427-675. (e) Linker, T. Adv. Synth. Catal. 1997, 339, 488492. (f) Nair, V.; Mathew, J.; Prabhakaran, J. Chem. Soc. Rev. 1997, 127-132. (g) Nair, V.; Balagopal, L.; Rajan, R.; Mathew, J. Acc. Chem. Res. 2004, 37, 21-30. (h) Nair, V.; Deepthi, A. Chem. Rev. 2007, 107, 1862-1891.
Table 2. Comparison of Oxidation Potentials, Calculated HOMO Energies, and Reactivities in CAN-Mediated Radical Reactions of Variously Configured and Protected Glycals 1

\begin{tabular}{|c|c|c|c|c|c|c|}
\hline entry & & D-glycal & $P G$ & $E_{0 x}{ }^{a}(\mathrm{~V})$ & $t^{b}(\mathrm{~h})$ & $\mathrm{HOMO}$ energy $^{c}(\mathrm{eV})$ \\
\hline 1 & $1 a$ & glucal & Ac & 1.87 & 6 & -9.66 \\
\hline 2 & $1 \mathrm{~b}$ & galactal & Ac & 1.89 & 6 & -9.72 \\
\hline 3 & $1 c$ & xylal & Ac & 1.76 & 6 & -9.63 \\
\hline 4 & 1d & maltal & $\mathrm{Ac}$ & 1.87 & 6 & -9.62 \\
\hline 5 & If & galactal & $\mathrm{Bn}$ & 1.62 & 2 & -9.36 \\
\hline 6 & $1 \mathrm{~g}$ & galactal & $\mathrm{Me}$ & 1.48 & 1 & -9.16 \\
\hline 7 & 1h & galactal & $\mathrm{SiMe}_{3}$ & 1.37 & $0.5^{e}$ & -8.55 \\
\hline 8 & $1 \mathbf{i}$ & galactal & $\mathrm{Si}(i-\mathrm{Pr})_{3}$ & $d$ & $d$ & -8.59 \\
\hline 9 & 1e & galactal & $\mathrm{H}$ & 1.35 & $0.5^{e}$ & -8.87 \\
\hline 10 & $2,3-$ & lihydropyran & 1.21 & $0.5^{e}$ & & -9.22 \\
\hline
\end{tabular}

${ }^{a}$ Oxidation potentials $E_{\mathrm{ox}}(\mathrm{V})$ vs ferrocene obtained from cyclic voltammograms. ${ }^{b}$ Reaction time until TLC showed complete conversion of glycal 1. ${ }^{c}$ HOMO energies computed by the semiempirical PM3 method implemented in MOPAC from Sybyl 8.0. All structures were minimized by the Tripos force field using the Gasteiger-Hückel method. ${ }^{d}$ Glycal $\mathbf{1 i}$ was not soluble in acetonitrile or methanol. ${ }^{e}$ Decomposition of glycal $\mathbf{1}$.

methylsilyl-protected (1h) glycals afforded only oxidative decomposition after short reaction times. An acid-catalyzed cleavage of the silyl groups is unlikely, due to the presence of sodium bicarbonate as the base. The triisopropylsilyl-protected glycals $\mathbf{1 i}$ and $\mathbf{1} \mathbf{j}$ were not soluble in methanol, and no reaction times were obtained (entries 9 and 10).

To further elucidate the influence of functional groups on the oxidation stability of glycals, we altered the substitution pattern at the 3-position (entries 11-16). Indeed, even a remote effect of para-substituents of the benzoate groups on the reaction time was established (entries 12-14), and again, the unprotected 3 -position afforded some oxidative byproduct (entry 11).

Finally, variation of the 1-position of glycals $\mathbf{1 q}-\mathbf{w}$ resulted in the strongest change in both reactivity and product distribution (entries 17-23). We performed the CAN-mediated addition of dimethyl malonate (2) to donor-substituted unsaturated carbohydrates for the first time, and the products $\mathbf{3 q}-\mathbf{t}$ were isolated in good yields in analytically pure form after only $1 \mathrm{~h}$ (entries 17-20, Supporting Information). On the other hand, acceptor groups reduced the rate of additions remarkably, and the unexpected ortho esters $\mathbf{4 v}$ and $\mathbf{4 w}$ were obtained in moderate yields as diastereomeric mixtures.

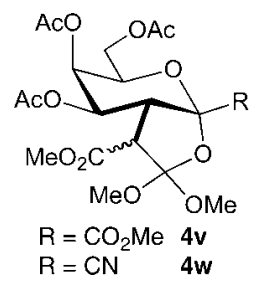

\section{Discussion}

Influence of the Configuration and the Protecting Groups on the Oxidation Stability of Glycals 1. With a large data set of oxidation potentials $\left(E_{\mathrm{ox}}\right)$ for variously substituted glycals $\mathbf{1}$ at hand, their electronic properties on one side and reactivities toward malonates on the other side can now be compared (Table 2). It is well-known that the addition of radicals to alkenes proceeds by orbital control, suggesting a strong interaction of the SOMO of the electrophilic malonyl radical with the HOMO 
Chart 2. Electron Density of the HOMO of Tri-O-benzyl-D-galactal (1f)

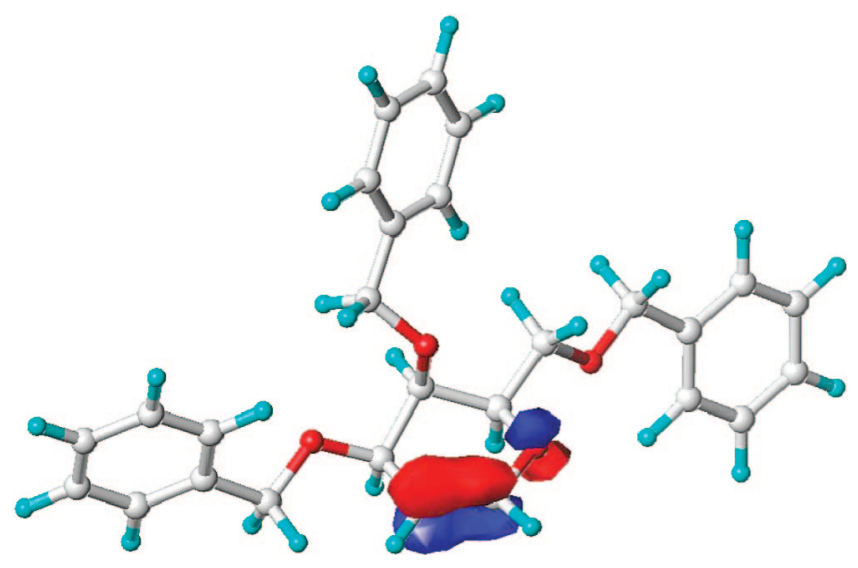

of the double bond component. ${ }^{29}$ This interaction is very sensitive to the substitution pattern and correlates directly with the rate of radical addition. Thus, if the HOMO energy is increased, the reaction with malonates is much faster, which is indicated qualitatively by the reaction times (Table 2). For the addition of malonyl radicals to para-substituted styrenes, detailed kinetics were measured and even Hammett correlations were obtained, irrespective of the generation of the radicals by CAN or tri- $n$-butyltin hydride. ${ }^{31}$ Likewise in our systems, the addition of the radicals to the double bond seems to be involved in the rate-determining step, apparently preceded by the formation of a cerium(IV)-malonyl radical complex in a preequilibrium. Indeed, if no glycal $\mathbf{1}$ was added to the reaction mixture, no conversion and decoloration of CAN was observed. To further investigate the importance of orbital interactions, HOMO energies were calculated by the semiempirical PM3 method. Indeed, the HOMO of tri- $O$-benzyl-D-galactal (1f) (Chart 2) has its highest electron density at the double bond, and thus, an oxidation of protecting groups is unlikely. Overall three parameters (oxidation potentials, reaction times, HOMO energies) are available to discuss the remarkable oxidation stability of glycals.

Although the reaction times may reflect the kinetics only qualitatively, they nicely correlate with the oxidation potentials. For example, the $O$-acetyl-protected derivatives $\mathbf{1 a}-\mathbf{d}$ with the highest $E_{\mathrm{ox}}$ (up to $1.89 \mathrm{~V}$ vs ferrocene; see entries $1-4$ ) reacted with the malonyl radicals only slowly. No influence of the configuration of the glycals $\mathbf{1}$ on the oxidation potential was observed; only di-O-acetyl-D-xylal (1c) has a slightly lower oxidation potential, due to one missing $O$-acetyl group. Thus, the functional groups seem to be responsible for the remarkable oxidation stability of glycals. In constrast, the completely unsubstituted 2,3-dihydropyran is oxidized already at $1.21 \mathrm{~V}$, furnishing only decomposition products with CAN after $30 \mathrm{~min}$ (entry 10).

To further understand the influence of protecting groups, a look at galactals $\mathbf{1 e}-\mathbf{i}$ (Table 2, entries 5-9) is highly instructive. A simple change from an $O$-acetyl to an $O$-benzyl group shifts the oxidation potential cathodically by a notable $270 \mathrm{mV}$. The same clear trend is reflected in the reaction times and especially the calculated HOMO energies (entries 2 and 5 ). For additional insight, we compared tri- $O$-acetyl-D-galactal

(31) Baciocchi, E.; Giese, B.; Farshchi, H.; Ruzziconi, R. J. Org. Chem. 1990, 55, 5688-5691. (1b) and tri- $O$-benzyl-D-galactal (1f) in a competition experiment. Dimethyl malonate (2) was added to a 1:1 mixture of both substrates in the presence of CAN, and the reaction was monitored by NMR spectroscopy at different times (Supporting Information). After $60 \mathrm{~min}, 82 \%$ of the electron-rich $O$-benzylprotected galactal 1f was consumed, whereas $70 \%$ of $\mathbf{1 b}$ remained unreacted. This difference in reactivity can be rationalized by the higher propensity of an ester group to withdraw electrons compared to a benzyl ether. However, since the functional groups are not directly linked to the double bond, this remarkable influence must be transmitted through space or $\sigma$-bonds. Such strong transmission was hitherto unknown for radical additions to glycals and will be discussed in the next section. Interestingly, this phenomenon can be considered as a new manifestation of the known arming-disarming effect of protecting groups observed and utilized in glycosylations. ${ }^{32}$ Although not directly comparable to radical additions, for such cationic reactions at the anomeric center, the influence of various functional groups over many bonds was semiquantified by Ley ${ }^{33}$ and Wong. ${ }^{34}$

To exclude a direct oxidation of the benzyl ethers, ${ }^{35}$ we investigated the corresponding tri- $O$-methyl-D-galactal (1g) equipped with oxidation-stable protecting groups. Its oxidation potential $\left(E_{\mathrm{ox}}=1.48 \mathrm{~V}\right.$ vs ferrocene, entry 6$)$ is even lower than that of the benzyl-protected galactal $\mathbf{1 f}$ (entry 5), in good accordance with the calculated HOMO energies. The addition of dimethyl malonate (2) in the presence of CAN proceeded with both substrates smoothly, without affecting the protecting groups (Table 1). Thus, the redox potentials indeed reflect the MO energies of the double bonds and not those of the protecting groups.

The limit for synthetic applications of cerium(IV)-mediated additions of radicals to glycals $\mathbf{1}$ was reached with silylsubstituted systems $\mathbf{1 h}$ and $\mathbf{1 i}$ or the unprotected D-galactal $\mathbf{1 e}$, since the unsaturated carbohydrates were not soluble or decomposed within minutes (entries 7-9). For glycal 1h, deprotection under the reaction conditions cannot be excluded, but the low oxidation potential of $1.37 \mathrm{~V}$ vs ferrocene is in the same range as that of 2,3-dihydropyran (1.21 V, entry 10), supporting an oxidation of the double bond. In summary, we established (i) the remarkable oxidation stability of glycals and (ii) a strong influence of protecting groups, thus providing a rationale for this unusual behavior. However, the way the protecting groups influence the oxidation potential of the enol ether structure through space or $\sigma$-bonds is not yet explained properly and will be discussed in the next section.

(32) (a) Collins, P. M.; Ferrier, R. J. Monosaccharides-Their Chemistry and Their Roles in Natural Products; John Wiley \& Sons: Chichester, U.K., 1995. (b) Fügedi, P. Oligosaccharide synthesis. In The Organic Chemistry of Sugars; Levy, D. E., Fügedi, P., Eds.; CRC Taylor \& Francis: Boca Raton, FL, 2006; pp 181-221. (c) Jensen, H. H.; Bols, M. Acc. Chem. Res. 2006, 39, 259-265.

(33) (a) Ley, S. V.; Priepke, H. W. M. Angew. Chem., Int. Ed. Engl. 1994 33, 2292-2294. (b) Cheung, M. K.; Douglas, N. L.; Hinzen, B.; Ley, S. V.; Pannecoucke, X. Synlett 1997, 257-260. (c) Green, L. G.; Hinzen, B.; Langer, P.; Ley, S. V.; Warriner, S. L. Synlett 1998, 440442. (d) Review: Green, L. G.; Ley, S. V. Carbohydr. Chem. Biol. 2000, 1, 427-448.

(34) (a) Zhang, Z.; Ollmann, I. R.; Ye, X.-S.; Wischnat, R.; Baasov, T; Wong, C.-H. J. Am. Chem. Soc. 1999, 121, 734-753. (b) Ye, X.-S.; Wong, C.-H. J. Org. Chem. 2000, 65, 2410-2431. (c) Mong, T. K. K.; Huang, C.-Y.; Wong, C.-H. J. Org. Chem. 2003, 68, 2135-2142.

(35) (a) Lines, R.; Utley, J. H. P. J. Chem. Soc., Perkin Trans. 21977, 803-809. (b) Boyd, J. W.; Schmalzl, P. W.; Miller, L. L. J. Am. Chem. Soc. 1980, 102, 3856-3862. (c) Baciocchi, E.; Piermattei, A.; Rol, C.; Ruzziconi, R.; Sebastiani, G. V. Tetrahedron 1989, 45, 70497062 . 
Table 3. Comparison of Oxidation Potentials, Calculated HOMO Energies, and Reactivities in CAN-Mediated Radical Reactions of Variously 3-Substituted Glycals 1

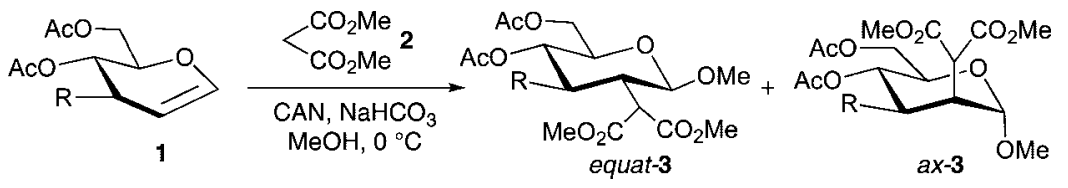

\begin{tabular}{|c|c|c|c|c|c|c|c|}
\hline entry & glucal & $\mathrm{R}$ & $E_{0 x}{ }^{a}(\mathrm{~V})$ & $t^{b}(\mathrm{~h})$ & HOMO energy $^{c}(\mathrm{eV})$ & eq-3 yield ${ }^{d}(\%)$ & $a x-3$ yield $(\%)$ \\
\hline 1 & 1a & $\mathrm{OAc}$ & 1.87 & 6 & -9.66 & 80 & 15 \\
\hline 2 & 11 & $\mathrm{O}_{2} \mathrm{CPh}$ & 2.03 & 12 & -9.80 & 78 & 16 \\
\hline 3 & $1 \mathrm{~m}$ & $\mathrm{O}_{2} \mathrm{CPh}-p$-OMe & 1.86 & 6 & -9.54 & 74 & 20 \\
\hline 5 & 10 & $\mathrm{O}_{2} \mathrm{CC}\left(\mathrm{CH}_{3}\right)_{3}$ & 1.94 & 6 & -9.70 & 75 & 16 \\
\hline 6 & $1 \mathrm{k}$ & $\mathrm{OH}$ & 1.67 & 2 & -9.52 & 45 & 3 \\
\hline 7 & $1 p$ & $\mathrm{H}$ & 1.62 & 2 & -9.47 & 47 & 40 \\
\hline
\end{tabular}

${ }^{a}$ Oxidation potentials $E_{\mathrm{ox}}(\mathrm{V})$ vs ferrocene obtained from cyclic voltammograms. ${ }^{b}$ Reaction time until TLC showed complete conversion of glycal $\mathbf{1}$. ${ }^{c}$ HOMO energies computed by the semiempirical PM3 method implemented in MOPAC from Sybyl 8.0. All structures were minimized by the Tripos force field using the Gasteiger-Hückel method. ${ }^{d}$ Yield of isolated product after column chromatography.

Influence of the Substituents at the 3-Position on the Oxidation Stability of Glycals 1. To find a mechanistic rationale for the remarkable influence of protecting groups on the oxidation stability of glycals, we varied the substitution pattern at the 3-position that is located adjacent to the double bond. To exclude poor overlap with the electrode by steric interactions, possibly leading to slow heterogeneous electron-transfer, we selected 3-O-pivaloylglucal 10 as a test substrate (entry 5). Even for this bulky substituent, the oxidation potential was in the expected range, suggesting that exclusively electronic effects are operative. The successful comparison of oxidation potentials, calculated HOMO energies, and reactivities was thus applied again (Table 3 ).

The change of the $O$-acetyl into an $O$-benzoyl group resulted in an anodic shift of the oxidation potential by $160 \mathrm{mV}$ and a longer reaction time (entry 2). Such findings can be explained by the slightly stronger acceptor propensity of the benzoyl group and are in accordance with a decrease in the HOMO energy by $140 \mathrm{mV}$. Even the remote para-substituent of the $O$-benzoyl group exerted an influence on the redox potential and reaction time, promoting a faster addition of malonyl radicals to the donor (OMe) than to the acceptor $\left(\mathrm{NO}_{2}\right)$ substituted system (entries 3 and 4). Why the benzoyl and $p$-nitrobenzoyl showed almost the same oxidation potential could not be explained until now, as the nitro compound 1 n displayed the lowest calculated HOMO energy $(-9.99 \mathrm{eV})$ in the whole series of 3-substituted glycals, about $190 \mathrm{mV}$ more negative than that of $\mathbf{1 l}(\mathrm{Ph})$. For the $(p-$ methoxybenzoyl)glucal $\mathbf{1 m}$, on the other hand, the oxidation potential and the computed HOMO energies are in due agreement (entry 3).

These influences of substituents are very interesting, since such remote effects over many bonds, including $\sigma$-bonds, were hitherto unknown in radical reactions. However, the results can again be compared with the stereoelectronic effects in glycosylation reactions, transmitted through space or $\sigma$-bonds as well. ${ }^{32-34}$ In contrast to the ester-substituted systems, the unprotected and 3-deoxy substrates exhibited considerably lower oxidation potentials and faster reaction times (Table 3 , entries 6 and 7), which can be explained by the lack of an acceptor group.

Our explanation for the remarkable influence of the substituents in the 3-position on the oxidation potentials and reactivities through $\sigma$-bonds is based on orbital interactions (Chart 3). Thus, electron acceptors such as esters are expected to lower the energy of the $\sigma^{*}$-orbital of the $\mathrm{C}-\mathrm{O}$ bond, resulting in a stronger
Chart 3. Orbital Interactions in Glycals $11-\mathbf{n}$

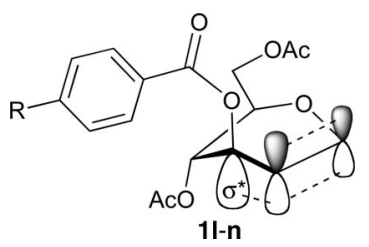

interaction with the adjacent HOMO of the double bond. As a result, the HOMO energy drops (as demonstrated by computations) and a higher oxidation potential is measured by cyclic voltammetry. Even the para-substituents $\mathrm{R}$ on the aromatic ring slightly influence the oxidation potentials (entries 2-4), which is also reflected in the calculations of the HOMO energies. For a perfect overlap, the $\sigma^{*}$ - and $\pi$-orbitals should adopt an almost parallel alignment, which is readily possible in the quite flexible ring system of glycals. The important influence of orbital interactions on the conformation of carbohydrates is nicely reflected in the structure of glycosyl radicals. ${ }^{36}$ In summary, we could provide a mechanistic rationale for the unusual oxidation stability of glycals by variation of the functional groups in the 3-position. The effect is transmitted through $\sigma$-bonds even up to the para-substituents of the benzoate rings, which might be important for the discussion of the redox behavior of other allylic systems.

Influence of the Substituents in the 1-Position on the Oxidation Stability of Glycals 1. With substituents in the 3-position already exhibiting a sizable influence on the HOMO energies of glycals, this effect is expected to be much stronger in the 1-position. Now the functional group is directly connected with the double bond and interacts by conjugation and not through $\sigma$-bonds. Indeed, glycals $\mathbf{1} \mathbf{u}-\mathbf{z}$ showed the broadest alteration of oxidation potentials, calculated HOMO energies, and reactivities (Table 4). Compared to tri- $O$-acetyl-D-glucal (1a), already the presence of a methyl group reduced the anodic peak potential in $\mathbf{1 q}$ by $300 \mathrm{mV}$ (entry 2), demonstrating the strong donor propensity of this substituent. Even lower oxidation potentials were obtained for the better electron-donating phenyl groups (entries 4 and 5), confirmed by the HOMO energies shifting from -9.66 to -9.52 and $-9.23 \mathrm{eV}$. The carbohydrate C-2 analogues $\mathbf{3 q}-\mathbf{t}$ were isolated in high yields (entries 2-5),

(36) Review: Praly, J.-P. Adv. Carbohydr. Chem. Biochem. 2000, 56, 65151. 
Table 4. Comparison of Oxidation Potentials, Calculated HOMO Energies, and Reactivities in CAN-Mediated Radical Reactions of Various 1-Substituted Glycals 1

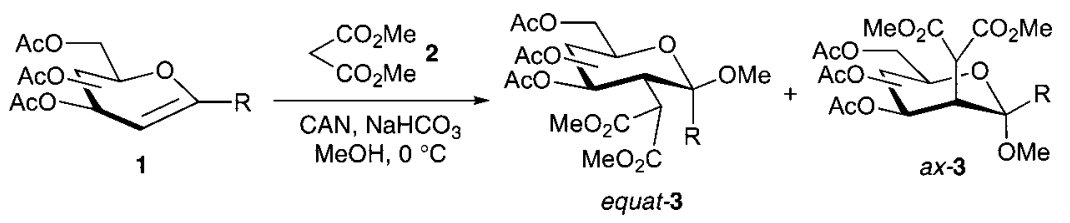

\begin{tabular}{|c|c|c|c|c|c|c|c|c|}
\hline entry & glycal & group in 4-position & $\mathrm{R}$ & $E_{0 x}{ }^{a}(\mathrm{~V})$ & $t^{b}(\mathrm{~h})$ & HOMO energy ${ }^{c}(\mathrm{eV})$ & eq-3 yield $(\%)$ & ax-3 yield $(\%)$ \\
\hline 1 & $1 \mathbf{a}$ & $e q$ & $\mathrm{H}$ & 1.87 & 6 & -9.66 & 80 & 15 \\
\hline 2 & $1 q$ & $e q$ & $\mathrm{Me}$ & 1.57 & 1 & -9.52 & 71 & \\
\hline 3 & $1 \mathbf{r}$ & $a x$ & $\mathrm{Me}$ & 1.55 & 1 & -9.43 & 73 & \\
\hline 5 & 1t & $a x$ & $\mathrm{Ph}$ & 1.35 & 1 & -9.17 & 82 & \\
\hline 6 & $1 \mathrm{u}$ & $a x$ & $\mathrm{CONH}_{2}$ & 1.96 & 8 & -9.80 & 70 & \\
\hline 7 & $1 \mathrm{v}$ & $a x$ & $\mathrm{CO}_{2} \mathrm{Me}$ & $>2.2^{e}$ & 12 & -10.03 & $38^{f}$ & \\
\hline
\end{tabular}

${ }^{a}$ Oxidation potentials $E_{\mathrm{ox}}(\mathrm{V})$ vs ferrocene obtained from cyclic voltammograms. ${ }^{b}$ Reaction time until TLC showed complete conversion of glycal $\mathbf{1}$. ${ }^{c}$ HOMO energies computed by the semiempirical PM3 method implemented in MOPAC from Sybyl 8.0. All structures were minimized by the Tripos force field using the Gasteiger-Hückel method. ${ }^{d}$ Yield of isolated product after column chromatography. ${ }^{e}$ No oxidation peak was observed, due to dominating oxidation of the bare electrolyte solution at $E_{\mathrm{ox}}>2.2 \mathrm{~V} .{ }^{f}$ Formation of ortho esters 4 and other minor side products.

and for the first time we prepared methyl glycosides with quaternary anomeric centers by this radical methodology.

On the other hand, 1-acceptor-substituted glycals $1 \mathbf{u}-\mathbf{w}$ reacted only sluggishly with dimethyl malonate (3a), most likely due to the remarkably lowered HOMO energies and consequential unfavorable orbital interactions. This is in accordance with other transition-metal-mediated radical reactions, which do not proceed efficiently with electron-poor alkenes. ${ }^{30}$ The cyclic voltammograms support this mechanistic rationale, since only the anodic current of the bare electrolyte solution $\left(E_{\mathrm{ox}} \approx\right.$ $2.1 \mathrm{~V}$ ) was observed for glycals $\mathbf{1 v}$ and $\mathbf{1 w}$ (entries 7 and 8). Therefore, the oxidation potentials of such acceptor-substituted unsaturated carbohydrates must be $>2.2 \mathrm{~V}$, a value never before observed for enol ethers. The difficult electrochemical oxidation of glycals $\mathbf{1 v}$ and $\mathbf{1 w}$ was confirmed by computations, as they showed the HOMO energies to be below $-10 \mathrm{eV}$. Thus, the orbital interaction of the electrophilic malonyl radicals with the double bond is drastically diminished, resulting in slower additions and lower yields. Additionally, the glycals $\mathbf{1 v}$ and $\mathbf{1 w}$ afforded ortho esters $\mathbf{4}$ and no methyl glycosides $\mathbf{3}$ as addition products in moderate yields (Table 3 , entries 7 and 8). The formation of such bicyclic compounds is interesting from the mechanistic point of view and was explained previously. ${ }^{11 \mathrm{c}}$

\section{Conclusions}

We established a remarkable oxidation stability of glycals and provide an explanation for their unusual reactivity and their application as valuable starting materials for other synthetic transformations. More than 20 variously substituted unsaturated carbohydrates were synthesized and investigated under oxidative reaction conditions. The method of choice was a combination of $\mathrm{CV}$, calculation of HOMO energies, and examination of the product distribution from cerium(IV)-mediated additions of radicals. Depending on the substitution pattern, the oxidation potentials of glycals were in the range of $1.35-2.03 \mathrm{~V}$ vs ferrocene. Compared with 2,3-dihydropyran $\left(E_{\mathrm{ox}}=1.21 \mathrm{~V}\right)$, such high values are unusual for enol ethers and demonstrate a remarkable oxidation stability of 1,2-unsaturated carbohydrates, which was hitherto disregarded. Moreover, the different reaction times for the addition of dimethyl malonate in the presence of CAN correlate nicely with the oxidation potentials and the HOMO energies. This was rationalized by the interaction of the SOMO of the electrophilic malonyl radical with the HOMO of the double bond.

The configuration of the glycals had no influence on their oxidation stability. On the other hand, a strong dependence of the oxidation potentials over $500 \mathrm{mV}$ on the protecting groups was found. Thus, $O$-silylated and unprotected glycals were readily oxidized to undesired side products, proving themselves as unsuitable substrates for radical additions under oxidative conditions. On the contrary, per- $O$-acetylated glycals exhibited the highest oxidation stability ( $E_{\text {ox }}$ up to $\sim 2 \mathrm{~V}$ ), but benzyl ethers were tolerated as well. These results are important for the general applicability of oxidation reactions in carbohydrate chemistry, with a high tolerance of various functional groups.

Interestingly, the protecting groups influence the oxidation stability of the enol ether structure through $\sigma$-bonds. This effect was verified by variation of the substitution pattern in the 3-position, with a remarkable spread of oxidation potentials over $400 \mathrm{mV}$. As a mechanistic model, we propose a favorable interaction of the $\sigma^{*}$-orbital of the adjacent $\mathrm{C}-\mathrm{O}$ bond with the HOMO of the double bond. Thus, electron acceptors in the allylic position lower the HOMO energy, which was nicely supported by calculations. This effect is transmitted even into the para-substituents of the benzoate rings, which may be important for the discussion of the redox behavior of other allylic esters.

Finally, donors and acceptors in the 1-position had the strongest influence on the oxidation stability, obviously due to the direct conjugation to the double bond. The potentials varied over a range of almost $1 \mathrm{~V}$, and the radical additions in the presence of CAN proceeded via different follow-up reactions. With strong acceptor groups, the intermediate radicals at the captodatively substituted anomeric center were not further oxidized, and ortho esters were isolated as carbohydrate $\mathrm{C}-2$ analogues.

Besides these new mechanistic aspects, the results are important for synthetic applications of transition-metal-mediated radical reactions in carbohydrate chemistry and the scope and limitations of the addition of $\mathrm{CH}$ acidic compounds to glycals. Due to oxidative decomposition by CAN, substrates with too low oxidation potentials are not suitable, whereas radical addition to glycals with a too high oxidation potential proceeds inefficiently. Thus, a window of $1.5-2.0 \mathrm{~V}$ for the oxidation potential seems to be ideal, provided by per- $O$-acetylated and -benzylated glycals. By following these guidelines, we expect 
many applications for the synthesis of C-2-branched carbohydrates or other oxidative transformations of glycals to arise in the near future.

Acknowledgment. This work was generously supported by the Deutsche Forschungsgemeinschaft (Grant Li 556/7-3), the Unversity of Debrecen, and the University of Siegen. We thank Dr. Holla (Norvartis) for a generous gift of the crude glycal $\mathbf{1 k}$.
Supporting Information Available: Experimental part including spectroscopic data and complete characterization of all new compounds and voltammograms of glycals $\mathbf{1}$. This material is available free of charge via the Internet at http:// pubs.acs.org.

JA8052706 